\title{
Evaluation of Lesson Study on Lines and Angles
}

\author{
Ke Yan ${ }^{1}$, Hui Deng ${ }^{2}$ Zhouli Huang ${ }^{3}$ \\ 1,2,3 Department of Mathematics and Statistics, Guangxi Normal University, China \\ 827562912@qq.com
}

\begin{abstract}
The intersection of two lines was studied in grade 7, junior high school. This geometry material is very important, as the basic 3 dimensions that students will learn at the high school level. Exploring and persuading the two properties of vertical lines is the most difficult thing in teaching. Traditional teaching uses methods such as observation, drawing, measurement, and comparison to derive the properties of vertical lines, and expresses the properties of vertical lines in finer words, which easily create greater difficulty for students to understand. This research uses research and development methods, tries to use mathematical software to teach lines and angles and optimizes the basic concept of lines and angles. The results of this study provide specific references to the graphs and geometry of junior high school mathematics.
\end{abstract}

Keywords: Lines and Angles, Technology, Lesson Study

\begin{abstract}
Abstrak
Perpotongan dua garis itu dipelajari di kelas 7, Sekolah Menengah Pertama. Materi geometri ini sangat penting, sebagai dasar materi dimensi 3 yang akan dipelajari siswa di jenjang SMA. Menggali dan meyakinkan dua sifat garis vertikal adalah hal tersulit dalam mengajar. Pengajaran tradisional menggunakan metode seperti observasi, menggambar, pengukuran, dan perbandingan untuk mendapatkan sifat-sifat garis vertikal, dan mengungkapkan sifat-sifat garis vertikal dengan kata-kata yang lebih halus, yang dengan mudah menciptakan kesulitan yang lebih besar bagi siswa untuk memahaminya. Penelitian ini menggunakan metode penelitian dan pengembangan, mencoba menggunakan perangkat lunak matematika untuk mengajarkan garis dan sudut serta mengoptimalkan konsep dasar garis dan sudut. Hasil penelitian ini memberikan referensi khusus pada grafik dan geometri matematika SMP.
\end{abstract}

Kata kunci: Garis dan Sudut, Teknologi, Lesson Study

Copyright (c) 2020 Ke Yan, Hui Deng, Zhouli Huang

$\triangle$ Corresponding author: 827562912@qq.com

Email Address: 827562912@qq.com

Received 29 November 2020, Accepted 05 Desember 2020, Published 09 Desember 2020

\section{INTRODUCTION}

The "Vertical Line" lesson comes from the content of "Intersecting Lines and Parallel Lines" in the second volume of the grade 7, Junior High School (Andriyani, 2018; X. Zhang, Zhou, \& Wijaya, 2020). It is an important content of material on geometry (Ikhsan \& Juandi, 2015). It is when students have a preliminary understanding of basic graphics points, lines and angles (Ramdhani \& Suryadi, 2018). A special positional relationship based on learning, initially infiltrating students' ideas from general to special, is the key content of the school, math material material is difficult to understand (Dewi, Mediyani, Hidayat, Rohaeti, \& Wijaya, 2019; T.T. Wijaya, Sukma, Purnama, \& Tanuwijaya, 2020). Traditional teaching is prone to two phenomena: one is to draw a vertical line of a known straight line through hands-on manipulation, and to directly give the nature of the vertical line through observation; the other is to obtain the shortest vertical line segment by measuring the line segment between the point and the straight line nature. Because the graphics are immutable and static, this kind of teaching is not conducive to the correct grasp of the nature of the vertical line, and it is 
difficult to grasp the nature of the vertical line. It is just a superficial study. Previous research has conducted the study of the effects of technology on mathematics (T.T. Wijaya, Jianlan, \& Aditya, 2020; T.T. Wijaya, Ying, \& Purnama, 2020b; Tommy Tanu Wijaya, Murni, Purnama, \& Tanuwijaya, 2020; Tommy Tanu Wijaya, Ying, Chotimah, \& Bernard, 2020; X. Zhang et al., 2020). This article tries to explore how to use dynamic mathematics technology to optimize teaching design, while highlighting the key points and solving the difficulties.

The "Compulsory Education Mathematics Curriculum Standard (2011 Edition)" pointed out that it is necessary to fully consider the impact of information technology on the content and methods of mathematics learning (Aixia, Ying, \& Wijaya, 2020), develop and provide students with abundant learning resources (Yi, Ying, \& Wijaya, 2019), and use modern information technology as a powerful tool for students to learn mathematics and solve problems Tools to effectively improve the way of teaching and learning (Lin, Zhou, Wang, \& Wijaya, 2020). Information technology to improve classroom teaching is the choice and requirement of the times (Suan, Ying, \& Wijaya, 2020; T.T. Wijaya, Purnama, \& Tanuwijaya, 2020; L. Zhang, Zhou, \& Wijaya, 2020). Mathematical dynamic technology can not only visually and dynamically present mathematical knowledge (Chotimah, Wijaya, Aprianti, Akbar, \& Bernard, 2020; Cunhua, Ying, Qunzhuang, \& Wijaya, 2019; Tan, Zou, Wijaya, Suci, \& Dewi, 2020), highlight the essence of mathematical concepts, and promote students' deep understanding of learning content (T.T. Wijaya, Ying, \& Purnama, 2020a), but also has the functions of strengthening students' hands-on operation, enhancing their interest in mathematical learning (Dikovic, 2009; Newhouse, 2017; Yu, Niemi, \& Mason, 2019), and improving students' learning methods. As a result, dynamic mathematics technology is deeply integrated into the mathematics classroom to provide guarantee for promoting students' in-depth learning and improving mathematics literacy (Chai, Lim, \& Tan, 2016; Koh, 2019; Listiawan, Purwanto, As'Ari, \& Muksar, 2018; Oner, 2020).

Based on the above guiding ideology, this class first designed the link of "reviewing the past and learning the new". In classroom teaching, introduction is an important link, and the quality of introduction directly affects the teaching effect of the entire class to some extent. From the review of the intersection of two straight lines, four corners will be formed. Through the change, the straight line is rotated to discover the special situation of the intersection, and then the concept of verticality is introduced; secondly, the link of "hands-on operation, inductive nature" is designed. Students have already drawn a point of a vertical line with a known straight line. The teacher dynamically displays the process of drawing a vertical line, guides students to observe the change of the vertical line when the position of the known line or point is changed, and allows students to conclude the first vertical line Article nature. Finally, design the link of "thinking about the problem and re-exploring the nature" and set the problem context. The teacher uses dynamic mathematics technology to dynamically present the length of the vertical line segment compared with the length of other line segments, and guide students to summarize the second nature of the vertical line. At the same time, 
the concept of "distance from point to straight line" is effectively established. Based on the abovementioned course ideas, the following is a record of the course creation of "the concept and nature of the vertical line".

\section{METHOD}

This study uses the Research and development (RnD) method (Abadi, Asih, \& Jupri, 2018). The researcher took a difficult junior high school material, then redesigned the learning using technology. The object of this research is the lines and angles material. Angles and lines material is in grade 7, Junior High School. The lesson plan consists of 3 sections, namely, the Opening Section, the main section and the discussion and evaluation section.

\section{RESULTS AND DISCUSSION}

\section{Opening Section}

Teacher: Earlier we learned that the intersection of two straight lines $\mathrm{AB}$ and $\mathrm{CD}$ can form four angles. If you rotate the straight lines $\mathrm{AB}$ and $\mathrm{CD}$, what will you find? (Dynamic presentation of the linear rotation process, as shown in Figure 1).
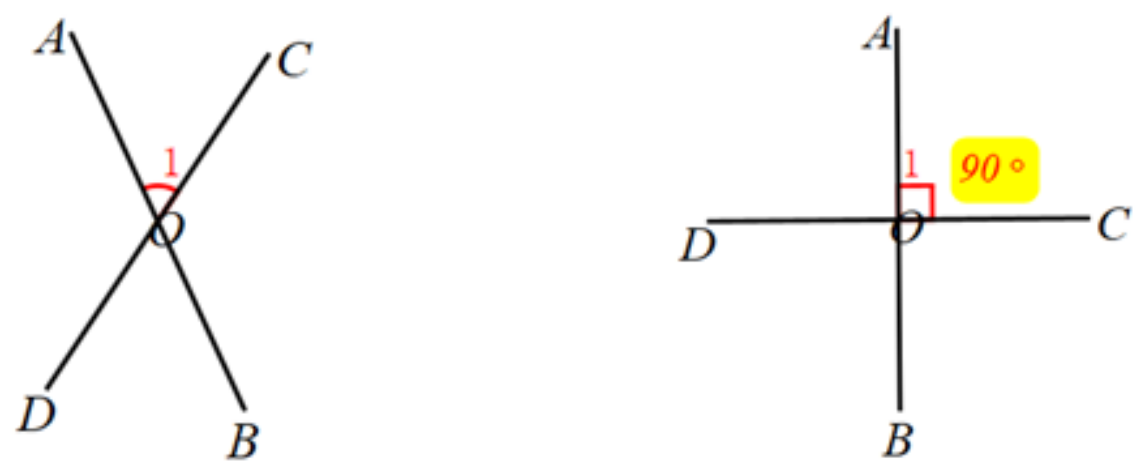

Figure 1. Two lines intersect

Student 1: With the rotation of the straight line, the size of the four corners formed will change.

Student 2: When the straight line rotates to a specific position, $\angle 1$ is equal to $90^{\circ}$, and the other angles are equal, which is also equal to $90^{\circ}$.

Teacher: Yes, when the straight line rotates to a certain position, the degrees of the four angles are all $90^{\circ}$. Mark $\angle 1$ with a right angle symbol. At this time, we call these two straight lines perpendicular to each other. That is, when one of the angles formed by the intersection of two straight lines is a right angle (it is easy to know that the other three angles are also right angles), the two straight lines are called perpendicular to each other, and one of the straight lines is called the 
perpendicular of the other straight line, and their intersection point It's called a vertical foot. Perpendicular is indicated by the symbol "", the straight line $\mathrm{AB}$ and $\mathrm{CD}$ are perpendicular to each other (O is the vertical foot), recorded as "AB CD", read as "AB perpendicular to $C D$ ".

\section{Main Section}

Teacher: After we understand the concept of vertical, if we give a point and a straight line, where the point can be on the straight line or outside the straight line, and it is required to draw a vertical line that passes through a known straight line, will students draw it? Please do it yourself.

Student 3: Because the drawn vertical line and the known straight line are perpendicular to each other, you only need to ensure that the angle formed by the intersection of the straight line passing through the point and the known straight line is $90^{\circ}$.

Teacher: How to ensure that the two intersecting straight lines are $90^{\circ}$ ? Which $90^{\circ}$ angle models have we been exposed to?

Student 4: You can use the right angle of a right triangle to draw a straight line that forms a $90^{\circ}$ angle with a known straight line, and ensure that the drawn straight line passes through point $P$.

Student 5: First measure $90^{\circ}$ with a protractor, then use two points to determine a straight line, and draw a vertical line passing through point $P$.

Teacher: Very good! Both of these methods can help us to draw a straight line that passes through the point $\mathrm{P}$ and is perpendicular to the straight line smoothly. (According to the students' answers, show the whole process of drawing the vertical line)

Teacher: Earlier we learned that there is a point outside the straight line and only one straight line is parallel to this straight line. So when we discuss the nature of the vertical line, it is the same. The vertical line of the known straight line is made through the point $\mathrm{P}$. How many such vertical lines can be made? Examine the point $\mathrm{P}$ on the straight line and the point $\mathrm{P}$ outside the straight line respectively.

Student 6: Only one vertical line can be drawn.

Teacher: Is this really the case? (The teacher changes the position of the known straight line or the point $\mathrm{P}$ respectively, and dynamically displays a point as a vertical line of the known straight line, there is always only one, as shown in Figure 2).

Student 7: Regardless of whether the point $\mathrm{P}$ is on a straight line or outside the straight line, only one vertical line can be drawn after P point.

Teacher: Very good! In the same plane, there is one and only one straight line perpendicular to the known straight line passing a point. This is the first property of the perpendicular. This property is also a basic fact recognized by everyone, and it is the basis for us to learn the second property of the vertical. 

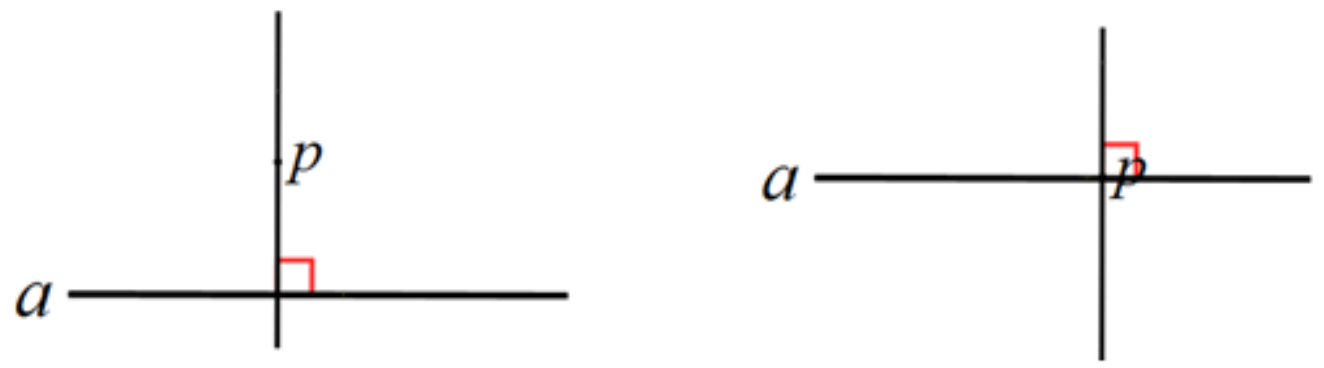

Figure 2. When two straight lines intersect, there is an angle equal to $90^{\circ}$

\section{Discussion and Evaluation Section}

Teacher: After learning the concept and basic facts of the vertical line, what practical use does the vertical line have in our lives?

Teacher: Have the students participated in the long jump?

All student: Past!

Teacher: Do you know how to accurately measure long jump performance? (Show the actual picture of the long jump, abstract the position of the starting board and the landing point)

Student 8: Use a line to connect the starting board and the landing point. The length of this line is the long jump performance.

Student 9 (doubt): But there are countless lines used to connect the launching board to the landing point. Which line is the length measured?

Teacher: There are countless line segments connecting the launching board and the landing point. That is, there will be countless lines crossing a known straight line. So how do you determine which one is? Is there any line that is special? (Show some examples of lines that intersect the straight line at one point, and mark the vertical situation with a red line)

Student 10: Among all the intersecting lines, there is only one vertical line.

Teacher: Yes, in the same plane, there is one and only one straight line perpendicular to the known straight line at a point. The line segment between the points connected by the vertical line and the straight line is called the vertical line segment. Does it have any mysterious characteristics? (Dynamic display of the length of the line segment between the point and the line, you can drag the point $\mathrm{P}$, as shown in Figure 3)

Student 11: The shortest vertical line segment.

Teacher: Very good! Among all the line segments connecting a point outside the line with each point on the line, the vertical line segment is the shortest. Or simply put it as the shortest vertical line segment. This is the second property of the vertical.

Teacher: After students understand this property, can they solve how to accurately measure the long jump performance in the long jump? why? 


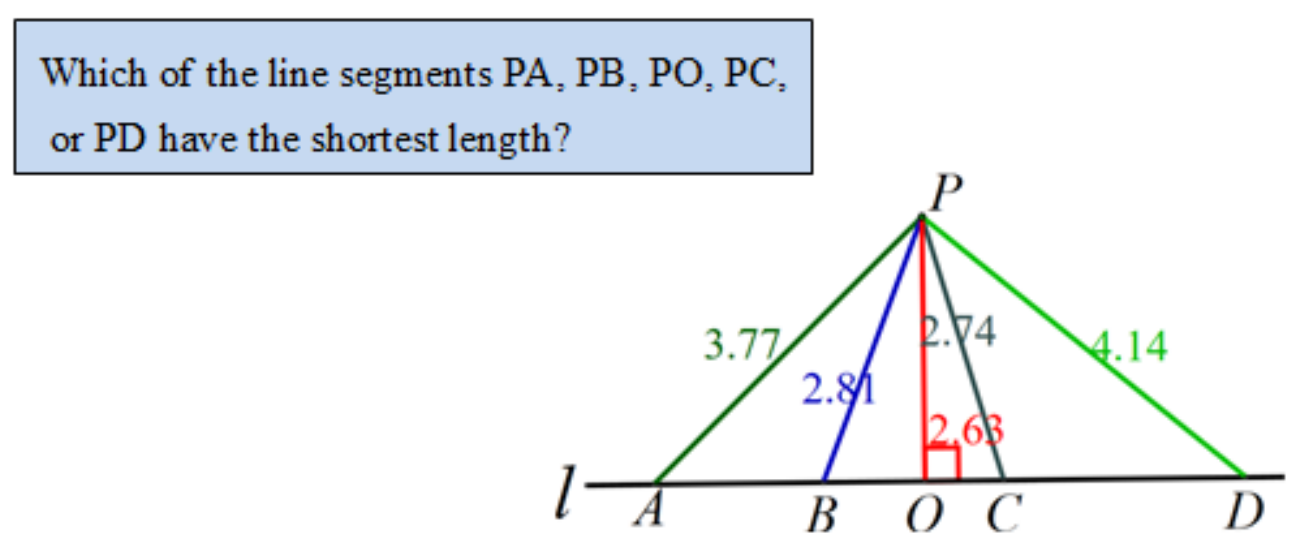

Figure 3. When two straight lines intersect, there is an angle equal to $90^{\circ}$

Student 12: You can measure the length of the vertical line between the landing point and the take-off board. This length is the distance of the long jump, that is, the long jump performance. Because the vertical line segment is the shortest.

Teacher: Very good! Because the vertical line segment is the shortest. And the length of the vertical line segment is the distance from the point to the straight line.

Teacher: Finally, we use a mind map to summarize the content of this lesson:

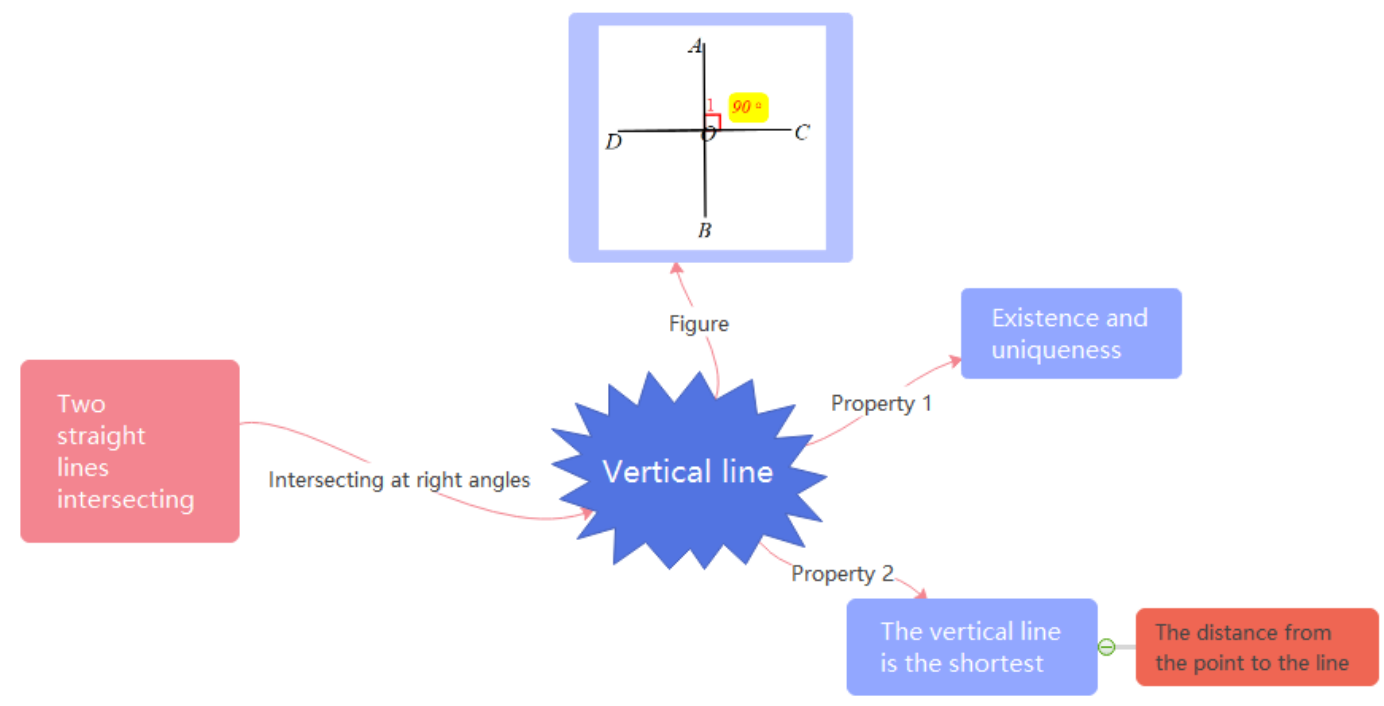

Figure 4. lines and angles mind map

This lesson will focus on breaking through a difficult point: the exploration of the two properties of vertical lines. Because these two properties are only obtained through drawing, measurement, and comparison, and the textual expression of the two properties is very concise, it will be difficult for students to summarize and understand. At the same time, the seventh grade students are mainly based on experience-based logical thinking. They need to go through the process of inquiry, accumulate experience in the process, and summarize the nature of the vertical line through guessing. Therefore, in teaching, teachers mainly use student experience as the starting point for new knowledge. Let 
students go through three links to understand the concept of vertical and master the two properties of vertical

Regarding the first property of the vertical line, the teacher first guides the students to do it by hand, draw a picture through a point to make a known straight vertical line, and then the students go through the process of drawing the vertical line, guess the first property, and finally the teacher passes Dynamically present "when changing the position of a known straight line or point, only a vertical line can still be drawn" to verify the conjecture. Regarding the second nature of the vertical line, the teacher first asks students how to accurately measure the performance of the long jump to stimulate students' thinking, and then introduces the concepts of vertical and oblique line segments, uses technology to measure the length of these line segments, and finally uses the form of dragging. Change the position of the point to abstract the concept of the distance from the point to the straight line, and then deduce the shortest vertical line segment. At the end of this lesson, organize the content of this lesson with a mind map, which is not only easy to remember knowledge, but also can effectively improve students' thinking ability and cultivate students' core qualities.

Of course, the above teaching process is not static. Teachers should make adjustments or changes according to their academic conditions to help students effectively understand and master the two properties of the vertical.

\section{CONCLUSION}

Lines and angles material has many formulas and theories that students must master. This study shows that using technology in learning can improve students' mathematical abilities and help students understand the lines and angles material. In the next research, a study can be carried out on the influence of technology learning media on lines and angles material to see the differences in the ability of classes that use technology and classes that do not use technology.

\section{ACKNOWLEDGEMENT}

The researcher thanks Tommy Tanu Wijaya who has helped author to revised this paper. The author also thanks Professor Tang Jianlan as a supervisor who always supports everything. This paper would not have been this good without the support of all parties.

\section{REFERENCES}

Abadi, M. K., Asih, E. C. M., \& Jupri, A. (2018). The Development of Interactive Mathematics Learning Material Based on Local Wisdom with .swf Format. Journal of Physics: Conference Series, 1013(1). https://doi.org/10.1088/1742-6596/1013/1/012131

Aixia, W., Ying, Z., \& Wijaya, T. T. (2020). The current situation and prospect of study quality evaluation research in china in the last 10 years. EDUKATIF: JURNAL ILMU PENDIDIKAN, 2(1), 101-112.

Andriyani, A. (2018). Analisis Kesalahan Siswa Dalam Menyelesaikan Soal Cerita Pada Materi 
Program Linear Ditinjau Dari Gaya Kognitif Siswa. Pendekar : Jurnal Pendidikan Berkarakter, 1(1), 16. https://doi.org/10.31764/pendekar.v1i1.252

Chai, C. S., Lim, C. P., \& Tan, C. M. (2016). Developing Teachers' Technological Pedagogical Mathematics Knowledge (TPMK) to Build Students' Capacity to Think and Communicate in Mathematics Classrooms. Future Learning in Primary Schools: A Singapore Perspective, 130 145. https://doi.org/10.1007/978-981-287-579-2

Chotimah, S., Wijaya, T. T., Aprianti, E., Akbar, P., \& Bernard, M. (2020). Increasing primary school students reasoning ability on the topic of plane geometry by using hawgent dynamic mathematics software Increasing primary school students reasoning ability on the topic of plane geometry by using hawgent dynamic mathematics. Journal of Physics: Conference Series, 1657(1), 012009. https://doi.org/10.1088/1742-6596/1657/1/012009

Cunhua, L., Ying, Z., Qunzhuang, O., \& Wijaya, T. T. (2019). Mathematics course design based on six questions cognitive theory using hawgent dynamic mathematic. Journal On Education, $02(01), 36-44$.

Dewi, D. P., Mediyani, D., Hidayat, W., Rohaeti, E. E., \& Wijaya, T. T. (2019). Analisis Kemampuan Berpikir Kritis Matematis Siswa Smp Pada Materi Lingkaran Dan Bangun Ruang Sisi Datar. JPMI (Jurnal Pembelajaran Matematika Inovatif), $2(6), \quad 371$. https://doi.org/10.22460/jpmi.v2i6.p371-378

Dikovic, L. (2009). Implementing dynamic mathematics resources with geogebra at the college level. International Journal of Emerging Technologies in Learning, 4(3), 51-54. https://doi.org/10.3991/ijet.v4i3.784

Ikhsan, M., \& Juandi, D. (2015). Analisis Penguasaan Siswa Sekolah Menengah Atas pada Materi Geometri. Didaktik Matematika, 2(1), 64-70.

Koh, J. H. L. (2019). Articulating Teachers' Creation of Technological Pedagogical Mathematical Knowledge (TPMK) for Supporting Mathematical Inquiry with Authentic Problems. International Journal of Science and Mathematics Education, 17(6), 1195-1212. https://doi.org/10.1007/s10763-018-9914-y

Lin, Y., Zhou, Y., Wang, S., \& Wijaya, T. T. (2020). Lesson design of geometric sequences based on the 6-question cognitive theory. Journal On Education, 02(04), 313-322.

Listiawan, T., Purwanto, P., As'Ari, A. R., \& Muksar, M. (2018). Mathematics Teachers Technological Content Knowledge (TCK) in using Dynamic Geometry Software. Journal of Physics: Conference Series, 1114(1). https://doi.org/10.1088/1742-6596/1114/1/012121

Newhouse, C. P. (2017). STEM the Boredom: Engage Students in the Australian Curriculum Using ICT with Problem-Based Learning and Assessment. Journal of Science Education and Technology, 26(1), 44-57. https://doi.org/10.1007/s10956-016-9650-4

Oner, D. (2020). A virtual internship for developing technological pedagogical content knowledge. Australasian Journal of Educational Technology, 36(2), 27-42. https://doi.org/10.14742/ajet.5192

Ramdhani, S., \& Suryadi, D. (2018). The analogical reasoning analysis of Pesantren students in geometry. Journal of Physics: Conference Series, 1132(012044). https://doi.org/10.1088/1742$6596 / 1132 / 1 / 012044$

Suan, L., Ying, Z., \& Wijaya, T. T. (2020). Using hawgent dynamic mathematics software in teaching arithmetic operation. International Journal of Education and Learning, 2(1), 25-31. https://doi.org/10.31763/ijele.v2i1.97 
Tan, S., Zou, L., Wijaya, T. T., Suci, N., \& Dewi, S. (2020). Improving student creative thinking ability with problem based learning approach using hawgent. Journal on Education, 02(04), 303-312.

Wijaya, T.T., Jianlan, T., \& Aditya, P. (2020). Developing an Interactive Mathematical Learning Media Based on the TPACK Framework Using the Hawgent Dynamic Mathematics Software. Emerging Technologies in Computing, 318-328. https://doi.org/10.1007/978-3-030-60036-5

Wijaya, T.T., Purnama, A., \& Tanuwijaya, H. (2020). Pengembangan Media Pembelajaran Berdasarkan Konsep Tpack pada Materi Garis dan Sudut Menggunakan Hawgent Dynamic Mathematics Software. JPMI - Jurnal Pembelajaran Matematika Inovatif, 3(3), 205-214. https://doi.org/10.22460/jpmi.v1i3.205-214

Wijaya, T.T., Sukma, M., Purnama, A., \& Tanuwijaya, H. (2020). Pengembangan media pembelajaran berbasis tpack menggunakan hawgent dynamic mathematics software. Journal of Elementary Education, 03(03), 64-72.

Wijaya, T.T., Ying, Z., \& Purnama, A. (2020a). The empirical research of hawgent dynamic mathematics technology integrated into teaching. Journal Cendekia: Jurnal Pendidikan Matematika, 04(01), 144-150.

Wijaya, T.T., Ying, Z., \& Purnama, A. (2020b). Using Hawgent Dynamic Mathematics Software in Teaching Trigonometry. International Journal of Emerging Technologies in Learning, 15(10), 215-222. https://doi.org/10.3991/ijet.v15i10.13099

Wijaya, Tommy Tanu, Murni, S., Purnama, A., \& Tanuwijaya, H. (2020). Pengembangan media pembelajaran berbasis tpack menggunakan hawgent dynamic mathematics software. COLLASE (Creative of Learning Students Elementary Education), 3(3), 64-72.

Wijaya, Tommy Tanu, Ying, Z., Chotimah, S., \& Bernard, M. (2020). Hawgent dynamic mathematic software as mathematics learning media for teaching quadratic functions Hawgent dynamic mathematic software as mathematics learning media for teaching quadratic functions. https://doi.org/10.1088/1742-6596/1592/1/012079

Yi, L., Ying, Z., \& Wijaya, T. T. (2019). The Trend of Mathematics Teaching Method Has Change From Fragments To Systematics. Journal Cendekia: Jurnal Pendidikan Matematika, 3(2), 471480. https://doi.org/10.31004/cendekia.v3i2.137

Yu, S., Niemi, H., \& Mason, J. (2019). Shaping Future Schools with Digital Technology - An International Handbook. https://doi.org/10.1007/978-981-13-9439-3

Zhang, L., Zhou, Y., \& Wijaya, T. T. (2020). Hawgent dynamic mathematics software to improve problem-solving ability in teaching triangles. Journal of Physics: Conference Series, 1663(1). https://doi.org/10.1088/1742-6596/1663/1/012069

Zhang, X., Zhou, Y., \& Wijaya, T. T. (2020). Hawgent Dynamic Mathematics Software to Teach Line and Angle. JNPM (Jurnal Nasional Pendidikan Matematika), 4(2), 237-247. 